\title{
The acute diuretic effect of an ethanolic fraction of Phyllanthus amarus (Euphorbiaceae) in rats involves prostaglandins
}

Alain N'guessan Yao ${ }^{1,3^{*}}$, Mamadou Kamagaté ${ }^{\prime}$, Augustin Kouao Amonkan², Philippe Chabert ${ }^{3}$, Fidèle Kpahé2 Camille Koffi', Mathieu N'goran Kouamé ${ }^{1}$, Cyril Auger ${ }^{3}$, Séraphin Kati-Coulibaly², Valérie Schini-Kerth ${ }^{3}$

and Henri Die-Kakou ${ }^{1}$

\begin{abstract}
Background: Phyllanthus amarus (Schum \& Thonn), a plant belonging to the family of Euphorbiaceae is used in Ivorian traditional medicine to treat cardiovascular disorders such as hypertension. However, although this plant has been described as a diuretic agent, the underlying mechanism remains unclear. Therefore, the aim of the present study was to investigate the mechanism action of diuretic effects of an ethanolic fraction of Phyllanthus amarus (EFPA) in rats.

Methods: Effects of EFPA on urinary excretion were carried out for doses ranging from 5 to $80 \mathrm{mg} / \mathrm{kg}$ given by intraperitoneal injection (i.p.) and compared with that induced by furosemide $(5 \mathrm{mg} / \mathrm{kg})$ after $8 \mathrm{~h}$. Thereafter, the diuretic activity of EFPA was also evaluated in the presence of indomethacin $(5 \mathrm{mg} / \mathrm{kg}$, i.p.) in order to determine the involvement of prostaglandins, after $24 \mathrm{~h}$.

Results: Between 5 and $80 \mathrm{mg} / \mathrm{kg}$, EFPA induced a significant urinary excretion. The profile of urinary excretion showed that after $2 \mathrm{~h}$, the highest dose of $80 \mathrm{mg} / \mathrm{kg}$ induced a urinary volumetric excretion (UVE), which was similar to that induced by furosemide. After $24 \mathrm{~h}$, EFPA at $10 \mathrm{mg} / \mathrm{kg}$ increased significantly UVE, $\mathrm{Na}^{+}(43 \mathrm{mEq})$ and $\mathrm{Cl}^{-}(97 \mathrm{mEq}$ ) urinary excretions without promoting kaliuresis. In rats pretreated with indomethacin, the urinary excretion and the natriuretic response of EFPA were significantly reduced.
\end{abstract}

Conclusion: Altogether, this study has shown that EFPA promotes a significant urinary excretion of water and $\mathrm{Na}^{+}$, confirming its diuretic activity. Moreover, the increased diuresis could be attributed, at least in part, to the involvement of prostaglandins.

Keywords: Phyllanthus amarus, Diuresis, Electrolytes, Prostaglandins

\section{Background}

The World Health Organization (WHO) encourages developing countries from the tropical area to develop therapeutic alternatives in the management of priority and emerging diseases such as high blood pressure and

\footnotetext{
* Correspondence: yalain08@yahoo.fr

1 Department of Pharmacology, UFR-SMA, Félix Houphouët-Boigny University, 01 BP V 166 Abidjan 01, Abidjan, Côte d'Ivoire

${ }^{3}$ UMR CNRS 7213, Laboratory of Biophotonics and Pharmacology, Faculty of Pharmacy, University of Strasbourg, Illkirch, France

Full list of author information is available at the end of the article
}

diabetes [1]. This strategy involves exploitation of the potential medicinal plants from the local pharmacopoeia. In this context, many studies on traditional medicine are undertaken in African countries against hypertension [2].

In Côte d'Ivoire, several traditional herbal preparations are used by the local population to treat hypertension, among them, Phyllanthus amarus (Schum \& Thonn), a plant belonging to the family of Euphorbiaceae [3]. This plant has various applications in traditional medicine throughout the world $[4,5]$. In the Ayurvedic medicine, decoctions of the whole plant are used to treat malaria 
[6], and skin disorders [7]. In traditional West African pharmacopoeia, particularly in Nigeria, the administration (per os) of decoctions of leaves and seeds extracts are used to treat diabetes [8].

Pharmacological studies in mice and rats have shown that Phyllanthus amarus has antiviral [5], hepatoprotective [9, 10] and hypoglycemic activities [11]. A previous study [12] has suggested that Phyllanthus amarus, described as diuretic agent, might be of interest in the treatment of hypertension. The antihypertensive activity of Phyllanthus amarus has been related to stimulation of muscarinic receptors leading to the formation of endothelium-derived nitric oxide (NO) and also to blocking of calcium channels $[13,14]$. Moreover, Phyllanthus species have been shown to have several beneficial effects on the vascular function. Phyllanthin and hypophyllanthin, two major compounds from Phyllanthus amarus, decreased vascular tone by endothelium-independent mechanisms via the blockade of $\mathrm{Ca}^{2+}$ entry into the vascular smooth muscle and inhibition of phenylephrine-induced $\mathrm{Ca}^{2+}$ release from the endoplasmis reticulum [15]. Phyllanthus acidus also inhibited vascular tone in aortic rings by acting directly on the smooth muscle and/or by releasing NO from the endothelium [16]. Moreover, 6 weeks after oral administration of an nbutanol extract of the leaves of Phyllanthus acidus, a decreased contractile response to phenylephrine and an enhanced endothelium-dependent relaxation to acetylcholine were observed in aortic rings of middle-aged male rats [17].

Furthermore, several studies have shown that natural products such as plant extracts from Hibiscus sabdariffa and Vepris heterophylla have diuretic properties, which might contribute to regulate blood pressure [18, 19]. It is well known that diuretics such as thiazides play a key role in the management of hypertensive diseases. They are most often associated with classic antihypertensive drugs such as angiotensin II type 1 receptor (AT1R) blockers to optimize blood pressure control. In this case, the role of diuretics is to potentiate the therapeutic effect of AT1R blockers by inducing a significant renal elimination of sodium and water.

The evaluation of the pharmacological effects of a Phyllanthus amarus aqueous extract administered intravenously in normotensive rabbits has shown that at doses ranging from 4.5 to $71.7 \mathrm{mg} / \mathrm{kg}$, the extract induced a transient decrease in mean arterial blood pressure of about $4.8 \pm 0.8$ to $14.0 \pm 0.6 \mathrm{mmHg}$ [14]. The ethanolic fraction was the most potent fraction inducing about a $11.5 \pm 0.5 \mathrm{mmHg}$ reduction of mean arterial blood pressure at $15 \mathrm{mg} / \mathrm{kg}$ [14]. In addition, it seemed to be the most potent extract for diuresis, however the mechanism action of these diuretic effect remain unclear [20]. The present study has evaluated the possibility that an ethanolic fraction of Phyllanthus amarus has a diuretic effect, which might contribute to reduce blood pressure.

\section{Methods}

\section{Plant material}

The whole plant of Phyllanthus amarus (Euphorbiaceae) was collected in the district of Cocody (Abidjan, Côte d'Ivoire) in April 2014. This plant has been authenticated by an expert in Botany (Professor Ake-Assi Laurent) at the Centre National de Floristique (UFR-Biosciences, Félix Houphouët-Boigny University, Abidjan, Côte d'Ivoire) where the voucher specimen was recorded under No. 3, 141 and 248.

\section{Extraction procedure}

The ethanolic fraction of Phyllanthus amarus (EFPA) was prepared as previously described with minor modifications [14]. Briefly, the whole plant was harvested, washed, and extracted in boiling distilled water for $30 \mathrm{~min}$ at ratio of $500 \mathrm{~g}$ of plant for $1 \mathrm{l}$. The decoction was filtered and then lyophilized to obtain a powder of aqueous extract of Phyllanthus amarus (11.72 g from $1 \mathrm{~kg}$ of plant). $3 \mathrm{~g}$ of lyophilisate were then dissolved in $250 \mathrm{ml}$ of a $70 \%$ ethanol solution and suspended into a separating funnel for $12 \mathrm{~h}$. The upper phase was separated and dried using a rotary evaporator (Büchi) to obtain powder of ethanolic fraction of Phyllanthus amarus (EFPA). Extraction procedure was repeated 5 times and, the final yield of EFPA preparation was $0.26 \%$.

\section{Pharmacological studies \\ Animal}

Male Wistar rats weighing between 180 and 250 g were used. Animals were randomly assigned 6 rats per group, including control, Furosemide $(5 \mathrm{mg} / \mathrm{kg})$, EFPA at different doses $(5,10,20,40$ and $80 \mathrm{mg} / \mathrm{kg})$, and EFPA $(10 \mathrm{mg} / \mathrm{kg})+$ indomethacin $(5 \mathrm{mg} / \mathrm{kg})$. They were bred in the animal house of the Ecole Normale Supérieure (Abidjan). Before starting the experiments, rats were isolated and acclimated for 14 days. They were maintained under standard laboratory conditions $\left(25 \pm 2{ }^{\circ} \mathrm{C}\right)$ with dark and light cycle $(12 / 12 \mathrm{~h})$ and had free access to a standard dry pellet diet and water ad libitum. Experiments were performed in accordance to the Guidelines for experiments involving animals [21, 22].

\section{Evaluation of the diuretic activity}

Diuretic activity was determined by the method described by Kau et al. (1984) with some modifications [23].

In the first step of experiments, the evaluation of the effects of different doses of the EFPA extracts on urinary excretion was carried out for doses ranging from 5 to $80 \mathrm{mg} / \mathrm{kg}$ body weight i.p. after an $8 \mathrm{~h}$ treatment period. The effect of Phyllanthus amarus extract was compared with that induced by Furosemide ( $5 \mathrm{mg} / \mathrm{kg}$, i.p.), used as a reference loop diuretic drug. The doses evaluated were 
below the maximal tolerated doses of Phyllanthus amarus administrated i.p. [24].

Thereafter, the diuretic effect of EFPA $(10 \mathrm{mg} / \mathrm{kg})$ was evaluated after $24 \mathrm{~h}$ in the presence of indomethacin ( $5 \mathrm{mg} / \mathrm{kg}$ ), a cyclooxygenase inhibitor, in order to evaluate the role of prostaglandins. Indomethacin was administered i.p. to rats $1 \mathrm{~h}$ prior to the administration of EFPA.

The administration of each test substance was preceded by fluid overloading with $50 \mathrm{ml} / \mathrm{kg}$ of water per os. Rats were placed individually in metabolic cages. Urine volumes were collected over either 8 or 24 h periods and were used to determine the urinary volumetric excretion $(\mathrm{U}$.

$\mathrm{VE}$ ) from the ratio of the volume of urine excreted and the volume of fluid overloaded. The urine volumes expressed as $\mathrm{mL} / 100 \mathrm{~g}$ were calculated based on body weight of rats and urinary volumetric excretion values are expressed as a percentage of the initial hydric overload $(50 \mathrm{~mL} / \mathrm{kg})$. At the end of the $24 \mathrm{~h}$ period, urine samples were collected and aliquoted into eppendorf tubes. Animals were anaesthetized by intraperitoneal injections of pentobarbital $(50 \mathrm{mg} / \mathrm{kg})$. The thoracic cavity was opened by surgical operation and blood was taken directly by heart puncture, put into heparinized tubes and, thereafter the plasma was obtained by centrifugation. Finally, animals were sacrificed by exsanguination. Both urine and plasma aliquots were stored at $-80{ }^{\circ} \mathrm{C}$ for subsequent biochemical analysis.

\section{Analytical procedures}

In order to determine the electrolyte content in plasma and urine samples, several techniques were used. The determination of sodium $\left(\mathrm{Na}^{+}\right)$and potassium $\left(\mathrm{K}^{+}\right)$contents was done by photometry, chlorine $\left(\mathrm{Cl}^{-}\right)$and urea concentrations by a colorimetric technique, and the calcium concentration by quantitative CPC method (o-cresolphthalein complexone). The creatinine content was estimated by the kinetics method.

\section{Drugs}

Furosemide was from Tocris Bioscience (Abingdon, UK) and indomethacin from Sigma (Saint Quentin Fallavier, France).

\section{Statistical analysis}

Data are expressed as mean \pm SEM. Statistical analysis of data was performed using GraphPad Instat software (Microsoft, San Diego, California, USA) and Graph Pad Prism software (Microsoft, San Diego, California, USA). Statistical analyses were assessed using one-way or twoway analysis of variance (ANOVA) followed by Bonferroni's post- test when applicable. Statistical significance was considered at $p<0.05$.

\section{Results}

\section{Effect of EFPA on urinary excretion}

Intraperitoneal administration of EFPA at doses ranging from 5 to $80 \mathrm{mg} / \mathrm{kg}$ body weight induced significant urinary excretion in a dose-dependent manner compared to the control group $(p<0.001$; Table 1; Additional file 1: Figure S1). After $8 \mathrm{~h}$, urinary excretion ranged from $41.2 \pm$ $3.3 \%$ to $63.3 \pm 3.2 \%$, respectively (Table 1 ; Additional file 1 : Figure S1). Urinary volumes excreted by the highest dose of EFPA $(80 \mathrm{mg} / \mathrm{kg}$ ) and $5 \mathrm{mg} / \mathrm{kg}$ of Furosemide were time dependent and significant compared to that of the control group ( $p<0.001$; Fig. 1$)$. After 2 h, Furosemide and EFPA caused similar urinary excretion, whereas at $8 \mathrm{~h}$, the effect of Furosemide was significantly greater than that of EFPA $(82.2 \% \pm 3.0$ versus $63.3 \pm 3.2 \%$, respectively at 8 h; Fig. 1$)$.

\section{Effect of indomethacin on EFPA-induced diuresis and excretion of electrolytes}

After $24 \mathrm{~h}$, EFPA at the dose of $10 \mathrm{mg} / \mathrm{kg}$ increased significantly the urinary volumetric excretion $(58.1 \pm 2.15 \%$; $p<0.05$; Fig. 2), compared with that of the control group $(16.8 \pm 2.29 \%$; $p<0.05$; Fig. 2). In presence of indomethacin, the urinary volumetric excretion of EFPA was significantly reduced, amounted to $33.1 \pm 3.5 \%(p<0.05$; Fig. 2), however, it remained greater than that of the control group ( $p<0.05$; Fig. 2).

After $24 \mathrm{~h}$, EFPA $(10 \mathrm{mg} / \mathrm{kg})$ induced a significant urinary excretion of sodium $(90.0 \pm 4.7 \mathrm{mEq} / \mathrm{L})$ compared to that of the control group $(70.50 \pm 6.1 \mathrm{mEq} / \mathrm{L}$; Table 2; Additional file 2: Figure S2). In rats pretreated with indomethacin $(5 \mathrm{mg} / \mathrm{kg})$, EFPA-induced natriuresis was significantly reduced to about $43.5 \pm 4.4 \mathrm{mEq} / \mathrm{L}(p<$ 0.05 ; Table 2; Additional file 2: Figure S2). In addition to sodium excretion, EFPA induced also a significant urinary excretion of $\mathrm{Cl}^{-}$from $81.2 \pm 3.1 \mathrm{mEq} / \mathrm{L}$ to $97.3 \pm$ $2.9 \mathrm{mEq} / \mathrm{L}$, which however was not affected by indomethacin (96.7 $\pm 4.1 \mathrm{mEq} / \mathrm{L}$; Table 2; Additional file 2: Figure S2). EAPA also caused a significant reduction in the urinary excretion of $\mathrm{K}^{+}$compared with that of the control group $(52.2 \pm 2.0 \mathrm{mEq} / \mathrm{L}$ versus $36.7 \pm 1.6 \mathrm{mEq} /$ $\mathrm{L}$, respectively in the control and EFPA group), but in the presence of indomethacin, excretion of $\mathrm{K}^{+}$was increased $(61.0 \pm 2.4 \mathrm{mEq} / \mathrm{L}$; Table 2; Additional file 2: Figure S2). The EFPA treatment did not significantly affect calciury in rats $(1.8 \pm 0.1$ versus $1.7 \pm 0.1 \mathrm{mEq} / \mathrm{L}$ in the control and EFPA group, respectively), also in presence of indomethacin $(3.1 \pm 0.2 \mathrm{mEq} / \mathrm{L}$; Table 2; Additional file 2: Figure S2).

\section{Effect of EFPA on plasma electrolyte levels}

Control group and rats treated with EFPA $(10 \mathrm{mg} / \mathrm{kg}$ for $24 \mathrm{~h})$ had similar natremia $(114.7 \pm 5.5$ and $125.5 \pm$ $4.0 \mathrm{mEq} / \mathrm{L}$, respectively; Table 3; Additional file 3: Figure S3), this effect was not affected in presence of indomethacin 
Table 1 Urinary excretion induced by increasing doses of EFPA in rats

\begin{tabular}{|c|c|c|c|c|c|c|c|c|}
\hline \multirow[t]{2}{*}{ Groups } & \multicolumn{4}{|c|}{ Urine volume $(\mathrm{mL} / 100 \mathrm{~g})$} & \multicolumn{4}{|c|}{ Urinary volumetric excretion (\%) } \\
\hline & $2 \mathrm{~h}$ & $4 \mathrm{~h}$ & $6 \mathrm{~h}$ & $8 \mathrm{~h}$ & $2 \mathrm{~h}$ & $4 \mathrm{~h}$ & $6 \mathrm{~h}$ & $8 \mathrm{~h}$ \\
\hline Control & $0.14 \pm 0.09$ & $0.20 \pm 0.07$ & $0.50 \pm 0.04$ & $0.70 \pm 0.05$ & $2.70 \pm 2.83$ & $3.80 \pm 1.10$ & $8.76 \pm 0.80$ & $13.62 \pm 0.92$ \\
\hline EFPA (5 mg/kg) & $0.84 \pm 0.11^{*}$ & $1.49 \pm 0.14^{*}$ & $1.73 \pm 0.20^{*}$ & $2.09 \pm 0.17^{*}$ & $16.61 \pm 2.01^{*}$ & $29.40 \pm 3.02^{*}$ & $34.20 \pm 3.64^{*}$ & $41.20 \pm 3.32^{*}$ \\
\hline EFPA (10 mg/kg) & $1.14 \pm 0.13^{*}$ & $1.82 \pm 0.11^{*}$ & $2.21 \pm 0.15^{*}$ & $2.80 \pm 0.20^{*}$ & $22.92 \pm 2.60^{*}$ & $36.50 \pm 2.53^{*}$ & $44.20 \pm 3.80^{*}$ & $55.94 \pm 3.40^{*}$ \\
\hline EFPA (20 mg/kg) & $1.67 \pm 0.15^{*}$ & $2.06 \pm 0.16^{*}$ & $2.34 \pm 0.10^{*}$ & $2.86 \pm 0.12^{*}$ & $33.30 \pm 4.10^{*}$ & $41.23 \pm 2.90^{*}$ & $46.80 \pm 2.70^{*}$ & $57.10 \pm 1.90^{*}$ \\
\hline EFPA (40 mg/kg) & $2.02 \pm 0.11^{*}$ & $2.34 \pm 0.10^{*}$ & $2.51 \pm 0.18^{*}$ & $3.09 \pm 0.13^{*}$ & $40.60 \pm 1.70^{*}$ & $47.12 \pm 2.83^{*}$ & $50.53 \pm 3.80^{*}$ & $60.20 \pm 2.90$ \\
\hline EFPA (80 mg/kg) & $2.33 \pm 0.12^{*}$ & $2.60 \pm 0.13^{*}$ & $2.92 \pm 0.13^{*}$ & $3.16 \pm 0.15^{*}$ & $46.61 \pm 2.10^{*}$ & $51.90 \pm 2.73^{*}$ & $58.41 \pm 1.91^{*}$ & $63.34 \pm 3.24$ \\
\hline
\end{tabular}

The urine volumes expressed as $\mathrm{mL} / 100 \mathrm{~g}$ were calculated based on body weight of rats and urinary volumetric excretion values are expressed as a percentage of the initial hydric overload $(50 \mathrm{~mL} / \mathrm{kg})$. Data are given as means \pm SEM of 6 different experiments. Statistical analyses were assessed using two-way analysis of variance (ANOVA) followed by Bonferroni's post- test. ${ }^{*} p<0.001$ versus control

$(119.3 \pm 4.4 \mathrm{mEq} / \mathrm{L}$; Table 3; Additional file 3: Figure S3). The plasma chlorine level observed in rats following the EFPA treatment was $102.0 \pm 4.3 \mathrm{mEq} / \mathrm{L}$, similar to that observed in the control group $(104.3 \pm 3.9 \mathrm{mEq} / \mathrm{L})$, and not affected by indomethacin $(103.3 \pm 3.4 \mathrm{mEq} / \mathrm{L}$; Table 3 ; Additional file 3: Figure S3). The potassium level was significantly reduced after EFPA treatment $(70.5 \pm 2.9$ versus $54.7 \pm 2.8 \mathrm{mEq} / \mathrm{L}$; respectively in the control and EFPA group), this effect was not affected by indomethacin (Table 3; Additional file 3: Figure S3). The plasma calcium level following EFPA treatment was similar to that of the control group $(5.2 \pm 2.6 \mathrm{mEq} / \mathrm{L}$ and $5.4 \pm 2.5 \mathrm{mEq} / \mathrm{L}$, respectively) and this response was not affected by indomethacin $(5.1 \pm 2.5 \mathrm{mEq} / \mathrm{L}$; Table 3; Additional file 3: Figure S3).

\section{Effect of EFPA on renal function}

After $24 \mathrm{~h}$, the EFPA treatment $(10 \mathrm{mg} / \mathrm{kg}$ for $24 \mathrm{~h})$ affected slightly but not significantly the plasma concentration of urea and creatinine in rats, both responses

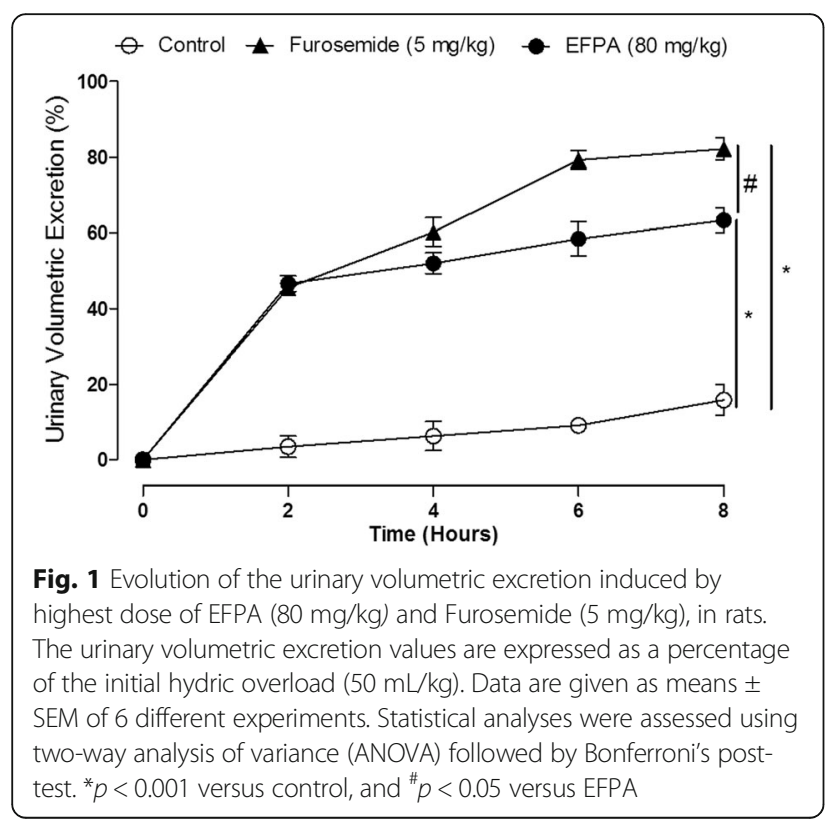

where significantly increased in presence of indomethacin (Table 4).

\section{Discussion}

The present findings indicate that an ethanolic fraction of Phyllanthus amarus (EFPA) at doses ranging from 5 to $80 \mathrm{mg} / \mathrm{kg}$, significantly induced diuresis during an $8 \mathrm{~h}$ period. The profile of urinary excretion showed that after $2 \mathrm{~h}$, at a dose of $80 \mathrm{mg} / \mathrm{kg}$, EFPA induced approximately the same UVE than that of $5 \mathrm{mg} / \mathrm{kg}$ of Furosemide. However, after $8 \mathrm{~h}$, the urinary excretion of Furosemide was greater $(82 \%)$ than that induced by the EFPA (63\%). Thus, these observations indicate that the diuretic effect of EFPA is relatively strong and sustained [25], as indicated by about $58 \%$ diuretic effect of EFPA at $10 \mathrm{mg} / \mathrm{kg}$ after $24 \mathrm{~h}$.

The effect of diuretic substances is commonly associated with the urinary excretion of electrolytes. The

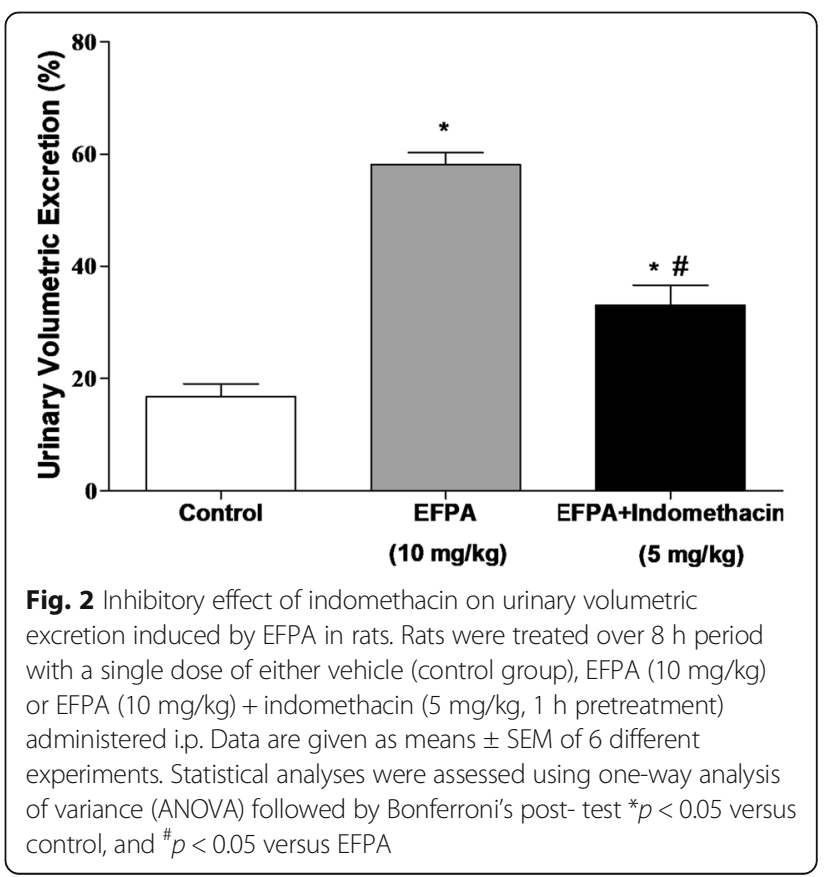


Table 2 Inhibitory effect of indomethacin on urinary electrolyte excretion induced by EFPA in rats

\begin{tabular}{|c|c|c|c|c|}
\hline \multirow[t]{2}{*}{ Groups } & \multicolumn{4}{|c|}{ Urinary concentrations (mEq/L) } \\
\hline & $\mathrm{Na}^{+}$ & $\mathrm{Cl}^{-}$ & $\mathrm{K}^{+}$ & $\mathrm{Ca}^{2+}$ \\
\hline Control & $70.50 \pm 6.05$ & $81.20 \pm 3.10$ & $52.20 \pm 2.01$ & $1.80 \pm 0.10$ \\
\hline EFPA (10 mg/kg) & $90.00 \pm 4.70^{*}$ & $97.33 \pm 2.90^{*}$ & $36.70 \pm 1.63^{*}$ & $1.73 \pm 0.10$ \\
\hline EFPA (10 mg/kg) + Indomethacin (5 mg/kg) & $43.50 \pm 4.43^{*}, \#$ & $96.70 \pm 4.10^{*}$ & $61.00 \pm 2.42^{*}, \#$ & $3.10 \pm 0.20$ \\
\hline
\end{tabular}

Rats were treated over a $24 \mathrm{~h}$ period with a single dose of vehicle (control group), EFPA (10 mg/kg) or EFPA (10 mg/kg) + indomethacin (5 mg/kg, $1 \mathrm{~h}$ pretreatment) administered i.p. Data are given as means \pm SEM of 6 different experiments. Statistical analyses were assessed using two-way analysis of variance (ANOVA) followed by Bonferroni's post- test. ${ }^{*} p<0.05$ versus control, and ${ }^{\#} p<0.05$ versus EFPA

Table 3 Inhibitory effect of indomethacin on plasma electrolyte level induced by EFPA in rats

\begin{tabular}{lccrr}
\hline Groups & \multicolumn{3}{c}{ Plasma levels (mEq/L) } \\
\cline { 2 - 5 } & $\mathrm{Na}^{+}$ & $\mathrm{Cl}^{-}$ & $\mathrm{K}^{+}$ & \multicolumn{2}{c}{$\mathrm{Ca}^{2+}$} \\
\hline Control & $114.70 \pm 5.51$ & $104.33 \pm 3.90$ & $70.50 \pm 2.90$ & $5.40 \pm 2.52$ \\
EFPA $(10 \mathrm{mg} / \mathrm{kg})$ & $125.50 \pm 4.00$ & $102.00 \pm 4.32$ & $54.70 \pm 2.80^{*}$ & $5.21 \pm 2.60$ \\
EFPA $(10 \mathrm{mg} / \mathrm{kg})+$ Indomethacin $(5 \mathrm{mg} / \mathrm{kg})$ & $119.33 \pm 4.43$ & $103.33 \pm 3.41$ & $50.83 \pm 5.10^{*}$ & $5.13 \pm 2.54$
\end{tabular}

Rats were treated over a $24 \mathrm{~h}$ period with a single dose of either vehicle (control group), EFPA (10 mg/kg) or EFPA (10 mg/kg) $+\mathrm{indomethacin} \mathrm{(5} \mathrm{mg/kg,} 1 \mathrm{~h}$ pretreatment) administered i.p. Data are given as means \pm SEM of 6 different experiments. Statistical analyses were assessed using two-way analysis of variance (ANOVA) followed by Bonferroni's post- test. * $p<0.05$ versus control, and ${ }^{*} p<0.05$ versus EFPA

Table 4 Effects of EFPA (10 mg/kg) and EFPA (10 mg/kg) + indomethacin (5 mg/kg, 1 h pretreatment) administered i.p. on plasma levels of creatinine and urea

\begin{tabular}{lccc}
\hline Groups & Control & EFPA $(10 \mathrm{mg} / \mathrm{kg})$ & EFPA $(10 \mathrm{mg} / \mathrm{kg})+\mathrm{Indomethacin}(5 \mathrm{mg} / \mathrm{kg})$ \\
\hline Creatinine $(\mu \mathrm{mol} / \mathrm{L})$ & $94.28 \pm 7.80$ & $88.40 \pm 4.56$ & $110.47 \pm 6.75^{\#}$ \\
Urea $(\mathrm{mmol} / \mathrm{L})$ & $4.08 \pm 0.38$ & $3.29 \pm 0.43$ & $5.83 \pm 0.58^{*}, \#$ \\
\hline
\end{tabular}

Data are given as means \pm SEM of 6 different experiments. Statistical analyses were assessed using one-way analysis of variance (ANOVA) followed by Bonferroni's post- test ${ }^{*} p<0.05$ versus control, and ${ }^{*} p<0.05$ versus EFPA

present findings indicate that EFPA induced important urinary excretion of sodium $(43 \mathrm{mEq})$ in consistent with previous observations showing that a preparation of the whole plant of Phyllanthus amarus caused significant urinary sodium excretion in hypertensive humans [12]. Furthermore, the EFPA-induced natriuresis was associated with urinary excretion of chlorine $(97 \mathrm{mEq})$ without promoting excretion of potassium. In addition, a leaf extract of Ficus exasperata (50 mg/kg, per os) also significantly decreased the plasma sodium level without promoting kaliuresis in rats [26].

Preliminary phytochemical analysis of EFPA revealed the presence of alkaloids, polyphenols, terpenes and sterols [14]. The diuretic effect of EFPA could be most likely related to these secondary active metabolites. Indeed, polyphenolic compounds, triterpenoids and saponins have been described to contribute to the diuretic effect of several plant extracts including Musanga cecropioides, Viscum angulatum, Hibiscus sabdariffa and Nigella sativa [27-30].

Furosemide, a highly effective loop diuretic induced considerable loss of water associated with an urinary excretion of sodium, chlorine and potassium. However, previous reports have also indicated that Furosemide did not affect significantly the efflux of potassium in normal rats [31, 32]. Thus, the EFPA treatment seems to induce a similar diuretic effect as that of Furosemide, without a loss of potassium. The main mechanism associated with loop diuretics is linked to inhibition of the co-transport system $\mathrm{Na}^{+} / \mathrm{K}^{+} / 2 \mathrm{Cl}^{-}$of the ascending limb of the loop of Henle [33]. Thus, EFPA could possibly act upon this part of the nephron to exert an inhibition of sodium chloride reabsorption and, hence, inducing a significant urinary elimination of water. Moreover, the diuretic effect of EFPA could also be related to other mechanisms such as affecting prostaglandin $\mathrm{E}_{2}\left(\mathrm{PGE}_{2}\right)$ formation, which regulates kidney function in the distal nephron by stimulating excretion of sodium via inhibition of vasopressinstimulated water and sodium absorption in the collecting duct $[34,35]$. In addition, $\mathrm{PGE}_{2}$ has been shown to play a key role in reducing vascular tone, and, hence, increasing renal blood flow leading to an increase of water exchange and transmembrane electrolyte, and an increased glomerular filtration rate $[36,37] . \mathrm{PGE}_{2}$ is synthesized by the cycloxygenase COX-1 and COX-2 located in the cortical zone of the renal tissue. Previous studies have indicated that inhibition of COX-1 and COX-2 with indomethacin resulted in retention of 
sodium and water associated with hypertension and edema in rats [34]. The present study indicates that treatment of rats with indomethacin significantly reduced the natriuretic and the diuretic responses of EFPA. These findings suggest that the diuretic properties of Phyllanthus amarus can be partially attributed, at least in part, to the involvement of diuretic prostaglandins. A similar mechanism has also been involved in the diuretic effect of several extracts of plant species used in traditional medicine such as Selaginella nothohybrida, Selaginella lepidophylla and Tropaeolum majus [31, 38].

The potassium-sparing effect of EFPA supposes also an action on the distal convoluted tubule and/or cortical collecting tube possibly by inhibiting the mineralocorticoid receptor, or with the exchanger $\mathrm{Na}^{+} / \mathrm{K}^{+}$by blocking sodium channels at the luminal membrane, respectively [25]. The present findings also indicate that Phyllanthus amarus could stimulate kidney function without causing an adverse effect on blood urea and creatinine [39].

\section{Conclusion}

The present findings indicate diuretic properties of an ethanolic fraction of Phyllanthus amarus aqueous extract associated with significant urinary excretion of $\mathrm{Na}^{+}$and water, which involves diuretic prostaglandins, supporting its use in traditional medicine as a potential remedy against hypertension. The diuretic activity of the Phyllanthus amarus extract might contribute to explain the hypotensive action shown previously in normal rabbits [14]. Further studies are needed to evaluate the effectiveness of EFPA in experimental models of hypertension, and to identify the bioactive compounds responsible for the diuretic properties.

\section{Additional files}

Additional file 1: Figure S1. Urinary volumetric excretion induced by increasing doses of EFPA in rats. The urinary volumetric excretion values are expressed as a percentage of the initial hydric overload $(50 \mathrm{~mL} / \mathrm{kg})$. Data are given as means \pm SEM of 6 different experiments. Statistical analyses were assessed using two-way analysis of variance (ANOVA) followed by Bonferroni's post- test. ${ }^{*} p<0.001$ versus control. (TIFF $216 \mathrm{~kb}$ )

Additional file 2: Figure S2. Inhibitory effect of indomethacin on urinary electrolyte excretion induced by EFPA in rats. Rats were treated over a $24 \mathrm{~h}$ period with a single dose of vehicle (control group), EFPA $(10 \mathrm{mg} / \mathrm{kg})$ or EFPA $(10 \mathrm{mg} / \mathrm{kg})+$ indomethacin $(5 \mathrm{mg} / \mathrm{kg}, 1 \mathrm{~h}$ pretreatment) administered i.p. Data are given as means \pm SEM of 6 different experiments. Statistical analyses were assessed using two-way analysis of variance (ANOVA) followed by Bonferroni's post- test. ${ }^{*} p<0.05$ versus control, and ${ }^{\#} p<0.05$ versus EFPA. (TIFF $140 \mathrm{~kb}$ )

Additional file 3: Figure S3. Inhibitory effect of indomethacin on plasma electrolyte level induced by EFPA in rats. Rats were treated over a $24 \mathrm{~h}$ period with a single dose of either vehicle (control group), EFPA $(10 \mathrm{mg} / \mathrm{kg})$ or EFPA $(10 \mathrm{mg} / \mathrm{kg})+$ indomethacin $(5 \mathrm{mg} / \mathrm{kg}, 1 \mathrm{~h}$ pretreatment) administered i.p. Data are given as means \pm SEM of 6 different experiments. Statistical analyses were assessed using two-way analysis of variance (ANOVA) followed by Bonferroni's post- test. ${ }^{*} p<0.05$ versus control, and ${ }^{\#} p<0.05$ versus EFPA. (TIFF $174 \mathrm{~kb}$ )

\section{Abbreviations}

\%: Percentage; $\mathrm{Cl}^{\text {: }}$ Chlorine; EFPA: Ethanolic fraction of Phyllanthus amarus; g: Gram; h: Hours; i.p: Intraperitoneal; K+: Potassium; L: Liter;

mEq: Milliequivalents; $\mathrm{Na}^{+}$: Sodium; SEM: Standard error mean; UVE: Urinary volumetric excretion

\section{Acknowledgements}

Authors are thankful to the authorities of Ecole Normale Supérieure (Abidjan) and those of UFR-Biosciences (Félix Houphouët-Boigny University, Abidjan, Côte d'lvoire) for providing support to the work. We are also grateful to Professor Ake-Assi Laurent team at the Centre National de Floristique (UFR-Biosciences, Félix Houphouët-Boigny University, Abidjan, Côte d'Ivoire).

\section{Funding}

This study was supported by a grant of the Service de Coopération et d'Action Culturelle of French Embassy of Côte d'Ivoire (Campus France Nº 767294B and $796998 \mathrm{H}$ ) and by a scholarship from the Ministère de l'Enseignement Supérieur et de la Recherche Scientifique of Côte d'Ivoire (Décision N 436/ MERS/DBE/SD-BHCl du 11/09/2013).

\section{Availability of data and materials}

All data generated or analysed during this study are included in this published article. The raw used and/or analysed during the current study can be available from the corresponding author on reasonable request. Plant material used in this study is registered under No. 3, 141 and 248 at the Centre National de Floristique (CNF) of Félix Houphouët-Boigny University, Abidjan, Côte d'Ivoire

\section{Authors' contributions}

Conceived and designed the experiments: AKA, MK, ANY, SKC and HDK Perfomed experiments: ANY, FK, MNK and KC. supervised the study: SKC and HDK. Analyzed the data: AKA, MK, ANY, KC, CA, VSK and HDK. Contributed reagents/materials/analysis tool: AKA and PC. Wrote the first draft of paper and contributed to manuscript preparation: ANY, MK, PC, CA, VSK, SKC and HDK. All authors read and approved the final manuscript.

\section{Ethics approval}

Animal experiments were performed with the authorization of Scientific Council of UFR-Biosciences of Félix Houphouët-Boigny University (2013/14), Abidjan, Côte d'Ivoire. Study was carried out following the Guidelines for experiments involving animals: the ARRIVE guidelines (published by Kilkenny et al., 2010 and McGrath et al., 2010).

\section{Consent for publication}

Not applicable.

\section{Competing interests}

The authors declare that they have no competing interest.

\section{Publisher's Note}

Springer Nature remains neutral with regard to jurisdictional claims in published maps and institutional affiliations.

\section{Author details}

${ }^{1}$ Department of Pharmacology, UFR-SMA, Félix Houphouët-Boigny University, 01 BP V 166 Abidjan 01, Abidjan, Côte d'Ivoire. 'Laboratory of Nutrition and Pharmacology, UFR-Biosciences, Félix Houphouët-Boigny University, Abidjan, Côte d'Ivoire. ${ }^{3}$ UMR CNRS 7213, Laboratory of Biophotonics and

Pharmacology, Faculty of Pharmacy, University of Strasbourg, Illkirch, France.

Received: 23 June 2017 Accepted: 7 March 2018

Published online: 15 March 2018

\section{References}

1. WHO. WHO traditional medicine strategy: 2002-2005 (2002). http://www. wpro.who.int. Accessed 15 Fev 2016

2. Liwa CA, Smart LR, Frumkin A, Epstein HAB, Fitzgerald DW, Peck RN. Traditional herbal medicine use among hypertensive patients in subSaharan Africa: a systematic review. Curr Hypertens Rep. 2014;16:437-9. 
3. N'guessan K, Tiébré MS, Aké-Assi E, Zirihi GN. Ethnobotanical study of plants used to treat arterial hypertension, in traditional medicine, by Abbey and Krobou populations of Agboville (Côte d'Ivoire). Eur J Sci Res. 2009;35:85-98.

4. Kuttan R, Harikumar KB. Phyllanthus species: scientific evaluation and medicinal applications. 1st ed. Boca Raton: CRC Press; 2012. p. 149-267.

5. Patel JR, Tripathi P, Sharma V, Chauhan NS, Dixit VK. Phyllanthus amarus: Ethnomedicinal uses, phytochemistry and pharmacology: a review. J Ethnopharmacol. 2011;138:286-313.

6. Keluskar $P$, Ingle $S$. Ethnopharmacology guided screening of traditional Indian herbs for selective inhibition of Plasmodium specific lactate dehydrogenase. J Ethnopharmacol. 2012;144:201-7.

7. Upadhyay B, Parveen AK, Dhaker AK, Kumar A. Ethnomedicinal and ethnopharmaco-statistical studies of eastern Rajasthan, India. J Ethnopharmacol. 2010;129:64-86.

8. Adeneye AA. The leaf and seed aqueous extract of Phyllanthus amarus improves insulin resistance diabetes in experimental animal studies. J Ethnopharmacol. 2012;144:705-11.

9. Faremi TY, Suru SM, Fafunso MA, Obioha UE. Hepatoprotective potentials of Phyllanthus amarus against ethanol-induced oxidative stress in rats. Food Chem Toxicol. 2008;46:2658-64.

10. Naaz F, Javed S, Abdin MZ. Hepatoprotective effect of ethanolic extract of Phyllanthus amarus Schum. Et Thonn. On aflatoxin B1 induced liver damage in mice. J Ethnopharmacol. 2007:113:503-9.

11. Adeneye AA, Amole OO, Adeneye AK. Hypoglycemic and hypocholesterolemic activities of the aqueous leaf and seed extract of Phyllanthus amarus in mice. Fitoterapia. 2006;77:511-4.

12. Srividya N, Periwal S. Diuretic, hypotensive and hypoglycemia effect of Phyllanthus amarus. Indian J Exp Biol. 1995;33:861-4.

13. Amaechina FC, Omogbai EK. Hypotensive effect of aqueous extract of the leaves of Phyllanthus amarus Schum and Thonn (Euphorbiaceae). Acta Pol Pharm. 2007;64:547-52.

14. Amonkan AK, Kamagaté $M$, Yao ANR, Konan AB, Kouamé MN, Koffi C, Kati-Coulibaly S, Die-Kakou H. Comparative effects of two fractions of Phyllanthus amarus (Euphorbiaceae) on the blood pressure in rabbit. Greener. J Med Sci. 2013;3:129-34

15. Inchoo $\mathrm{M}$, Chirdchupunseree $\mathrm{H}$, Pramyothin $\mathrm{P}$, Jianmongkol S. Endotheliumindependent effects of phyllanthin and hypophyllanthin on vascular tension. Fitoterapia. 2011;82:1231-6.

16. Leeya Y, Mulvany MJ, Queiroz EF, Marston A, Hostettmann K, Jansakul C. Hypotensive activity of an n-butanol extract and their purified compounds from leaves of Phyllanthus acidus (L.) Skeels in rats. Eur J Pharmacol. 2010;649:301-13.

17. Chongsa W, Kanokwiroon K, Jansakul C. Effects of 6 weeks oral administration of Phyllanthus acidus leaf water extract on the vascular functions of middle-aged male rats. J Ethnopharmacol. 2015;176:79-89.

18. Ntchapda F, Bonabe C, Kemeta Azambou DR, Talla E, Dimo T. Diuretic and antioxidant activities of the aqueous extract of leaves of Vepris heterophylla (Engl.) R. Let (Rutaceae) in rats. BMC Complement Altern Med. 2016;16:516.

19. Wright $\mathrm{Cl}$, Van-Buren $\mathrm{L}$, Kroner $\mathrm{Cl}$, Koning MM. Herbal medicines as diuretics: a review of the scientific evidence. J Ethnopharmacol. 2007;114:1-31.

20. Yao NG, Kamagaté M, Amonkan AK, Koffi C, Kpahe F, Kouamé MN, DiéKacou H. Comparative effects of aqueuos extract of Phyllanthus amarus and its fractions on urinary excretion in rat. J Phytopharmacol. 2016:5:182-4.

21. Kilkenny C, Browne WJ, Cuthill IC, Emerson M, Altman DG. Improving bioscience research reporting: the ARRIVE guidelines for reporting animal research. PLoS Biol. 2010;8:e1000412.

22. McGrath JC, Drummond GB, McLachlan EM, Kilkenny C, Wainwright CL. Guidelines for reporting experiments involving animals: the ARRIVE guidelines. Br J Pharmacol. 2010;160:1573-6.

23. Kau ST, Keddi JR, Andrews D. A method for screening diuretic agents in the rat. J Pharmacol Methods. 1984;11:67-75.

24. Coulibaly FA, Djyh BN, Doumbia I, Yapi HF, Djaman AJ. Évaluation des marqueurs sériques enzymatiques du cœur chez les lapins traités par Phyllanthus amarus (Euphorbiacées). Phythothérapie. 2010;8:348-52.

25. Ernst ME, Gordon JA. Diuretic therapy: key aspects in hypertension and renal disease. J Nephrol. 2010;23:487-93.

26. Amonkan AK, Konan AB, Ahui BML, Bleyéré MN, Kouakou LK, Bouaffou GMK Diuretic effects of extract of Ficus exasperata Vahl. Leaves in rat. Pak J Biol Sci. 2013;16:1383-7.
27. Dongmo AB, Kamanyi A, Boplet M. Saponins from the leaves of Musanga cecropioides (Cecropiaceae) constitute a possible source of potent hypotensive principles. Phytother Res. 1996;10:23-7.

28. Jadhav RB, Bhatnagar SP, Surana SJ. Diuretic activity of squamate mistletoe, Viscum angulatum. Pharm Biol. 2010;48:417-21.

29. Jiménez-Ferrer E, Alarcón-Alonso J, Aguilar-Rojas A, Zamilpa A, JiménezFerrer Cl, Tortoriello J, Herrera-Ruiz M. Diuretic effect of compounds from Hibiscus sabdariffa by modulation of the aldosterone activity. Planta Med. 2012:78:1893-8.

30. Toma C, Olah N, Vlase L, Mogoșan C, Mocan A. Comparative studies on polyphenolic composition, antioxidant and diuretic effects of Nigella sativa L. (black cumin) and Nigella damascena L. (lady-in-a-mist) seeds. Molecules. 2015:20:9560-74.

31. Gasparotto A Jr, Boffo MA, Lourenço EL, Stefanello ME, Kassuya CA, Marques MC. Natriuretic and diuretic effects of Tropaeolum majus (Tropaeolaceae) in rats. J Ethnopharmacol. 2009;122:517-22.

32. Lahlou S, Tahraoui A, Israili Z, Lyoussi B. Diuretic activity of the aqueous extracts of Carum carvi and Tanacetum vulgare in normal rats. J Ethnopharmacol. 2006;110:458-63.

33. Jaggi AS, Kaur A, Bali A, Singh N. Expanding spectrum of sodium potassium chloride co-transporters in the pathophysiology of diseases. Curr Neuropharmacol. 2015:13:369-88.

34. Breyer MD, Breyer RM. Prostaglandin E receptors and the kidney. Am J Physiol Renal Physiol. 2000;279:F12-23.

35. Madeddu P, Emanueli C, El-Dahr S. Mechanisms of disease: the tissue kallikrein-kinin system in hypertension and vascular remodeling. Nat Clin Pract Nephrol. 2007:3:208-21.

36. Lamas S, Rodríguez-Puyol D. Endothelial control of vasomotor tone: the kidney perspective. Semin Nephrol. 2012;32:156-66.

37. Sato M, Nakayama T, Soma M, Aoi N, Kosuge $K$, Haketa A, Izumi Y, Matsumoto K, Sato N, Kokubun S. Association between prostaglandin E2 receptor gene and essential hypertension. Prostaglandins Leukot Essent Fatty Acids. 2007;77:15-20.

38. Aguilar Ml, Benítez WV, Colín A, Bye R, Ríos-Gómez R, Calzada F. Evaluation of the diuretic activity in two Mexican medicinal species: Selaginella nothohybrida and Selaginella lepidophylla and its effects with ciclooxigenases inhibitors. J Ethnopharmacol. 2015:163:167-72.

39. Lawson-Evi P, Eklu-Gadegbeku K, Agbonon A, Moukha KS, Creppy EE, Gbésassor G. Toxicological assessment on extracts of Phyllanthus amarus Schum and Thonn. Sci Res Essays. 2008;3:410-5.

\section{Submit your next manuscript to BioMed Central and we will help you at every step:}

- We accept pre-submission inquiries

- Our selector tool helps you to find the most relevant journal

- We provide round the clock customer support

- Convenient online submission

- Thorough peer review

- Inclusion in PubMed and all major indexing services

- Maximum visibility for your research

Submit your manuscript at www.biomedcentral.com/submit 